\title{
JOÃO BATISTA DE LA SALLE (1651-1719): um silêncio eloquente em torno do educador católico que modelou a escola moderna
}

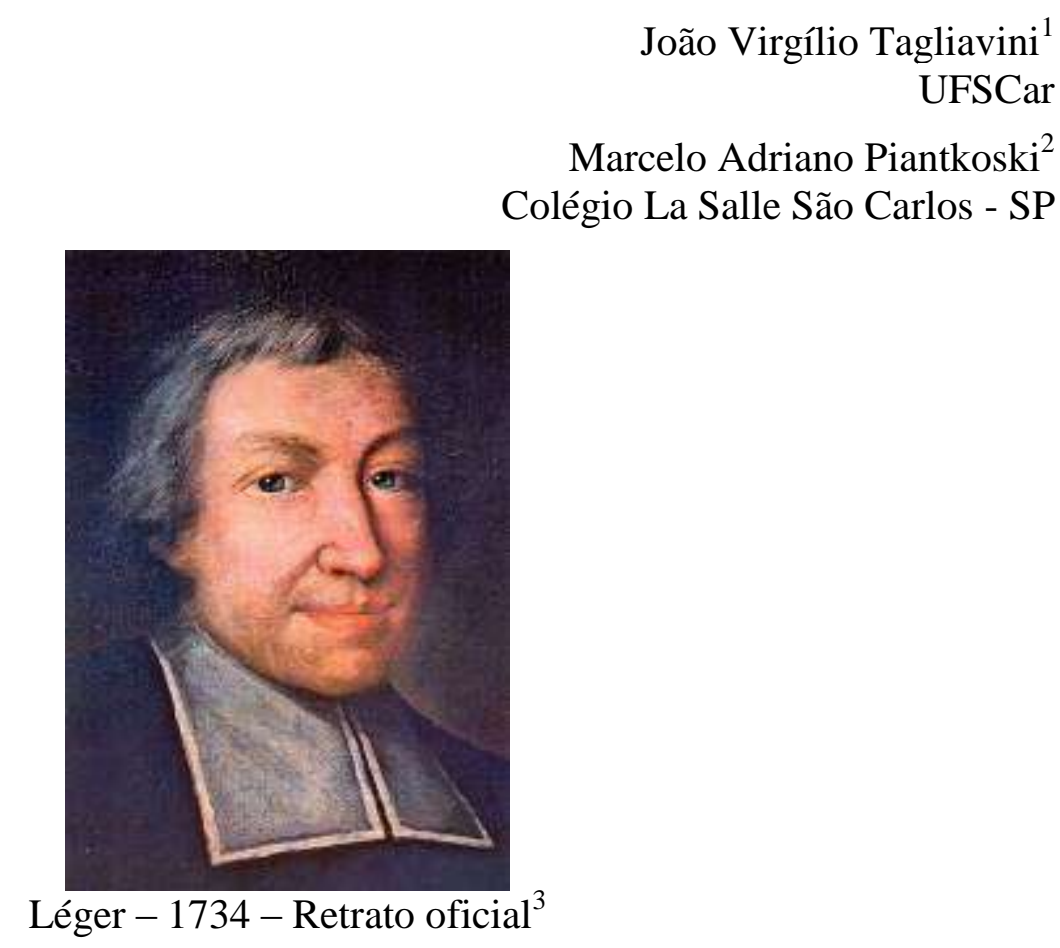

\section{RESUMO}

Ensaio sobre a vida e a obra educacional de João Batista de La Salle, França (1651-1719), fundador da congregação dos Irmãos das Escolas Cristãs e autor, com a colaboração deles, do Guia das Escolas Cristãs (1706). O ensaio oferece ao leitor as fontes para o estudo de um educador importante na constituição da escola moderna e contemporânea ocidental, e por consequência, no Brasil, porém bastante esquecido na maioria dos manuais utilizados em nossos cursos de graduação e pós-graduação. Com a tradução em língua portuguesa de suas Obras completas propõe-se o avanço nos estudos para o preenchimento de uma lacuna na historiografia da educação no Brasil.

Palavras-Chave: La Salle; Guia das Escolas Cristãs; educação católica; Irmãos Lassalistas.

\section{JOÃO BATISTA DE LA SALLE (1651-1719): an eloquent silence around the Catholic educator that shaped the modern school}

\begin{abstract}
Essay related to the life and educational work from Joao Batista de La Salle, France (1651 - 1719), founder of Brother of the Christian Schools Congregation as well as author, with their full collaboration, of Christian Schools Guideline (1706). Such essay offers to the reader the sources for the study of one important educator at the constitution of modern and occidental contemporary school, and in consequence in Brazil, however not always remembered at the most of the used guidelines in our graduation and post-graduation courses. The translation of his finished works in Portuguese propose the advance of studies to fill in the gap at educational historiography in Brazil.
\end{abstract}

Keywords: La Salle; Christian Schools Guideline, Catholic Education, Lasallian Brothers 


\section{Introdução}

Este ensaio nasceu da necessidade de preenchimento de uma lacuna na historiografia dos educadores estudados nos cursos de pedagogia, nas licenciaturas e nos programas de pós-graduação no Brasil. Com exceção dos jesuítas, pouco se estuda sobre os documentos e os fundamentos da educação católica na constituição da escola moderna na Europa e, por consequência, na América Latina e no Brasil. O estudante brasileiro é formado na graduação pelos manuais e quando chega à pós-graduação já está (de)formado. Pesquisando os principais manuais utilizados, verificou-se que apenas História da Educação de Mário Manacorda dá atenção à obra de La Salle. Quanto aos outros, há um silêncio eloquente. Quando, no primeiro semestre de 2013, elaboramos o programa de uma disciplina na pós-graduação em educação na UFSCar, tendo por objeto de estudo os documentos que organizaram a educação católica na modernidade europeia, tínhamos uma questão para responder: qual a contribuição da educação católica na constituição da escola moderna e o que sobreviveu na organização da escola contemporânea? Mas, outras perguntas e constatações surgiram na oferta da disciplina: por que, até agora não conhecíamos nada disso? Muitas e muitas propostas educacionais que são apresentadas como "novidades" estão sobejamente desenvolvidas no Guia das Escolas de João Batista de La Salle, elaborado com a contribuição dos Irmãos, em 1706. Estas eram afirmações constantes dos alunos da disciplina Estudos avançados em filosofia da educação.

Dentre as escolas estudadas, João Virgílio Tagliavini, coordenador da disciplina, e Marcelo Piantkoski, colaborador, elaboraram este ensaio sobre um pensador educacional com grande influência pedagógica, e na organização das escolas da França na passagem do século XVII para o Século XVIII. Sua obra e pensamento ainda são quase desconhecidos no Brasil, embora seus educadores, os Irmãos Lassalistas, e seus colégios, estejam presentes na educação brasileira desde 1907. Um aspecto inovador de sua obra, numa França que primava pela fortíssima desigualdade social, era a escola gratuita para ricos e pobres estudarem juntos, e com ensino simultâneo.

Uma das grandes dificuldades para o estudo das obras de La Salle era o acesso a elas em língua portuguesa. Pois isso foi resolvido: acabam de ser lançadas as Obras completas de La Salle, além do Guia das Escolas Cristãs, em edição à parte, em língua portuguesa. Um dos objetivos deste ensaio é a apresentação dessas obras e de outras fontes, inclusive virtuais, para os pesquisadores interessados no preenchimento dessa lacuna na historiografia educacional.

\section{Quem foi La Salle}

A França no final do século XVII e início do XVIII estava envolvida em constantes guerras e havia um contraste entre a miséria do povo e o luxo de uma pequena parcela da nobreza, do clero que girava ao redor de um poder real absoluto. Era um contexto clerical acentuado, herdado da idade média, com a organização social quase estamental, em que a nobreza e o clero católico viviam do suor do restante da população. As condições de vida e desenvolvimento humano eram precários, com alto índice de mortalidade infantil e expectativa de vida baixa.

A França foi governada por Luís XIV e quase todo o reinado coincidiu com a vida de La Salle. Pode-se fazer assim um quadro sinótico entre La Salle, Luiz XIV e o Palácio de Versalhes: 


\begin{tabular}{|l|c|c|c|c|}
\hline & Nascimento & $\begin{array}{c}\text { Início do } \\
\text { Reinado }\end{array}$ & Inauguração & Morte \\
\hline Luiz XIV & 1638 & $1661^{4}$ & & 1715 \\
\hline Versalhes & & & 1682 & \\
\hline La Salle & 1651 & & & 1719 \\
\hline
\end{tabular}

Se o povo miserável passava fome, tinha frio, e vivia, em média, apenas algumas décadas, o Palácio de Versalhes era a manifestação esplendorosa do luxo e do esbanjamento acintoso com os seus 700 quartos, 1.250 lareiras, 2.153 janelas, 700 hectares de parques. Em 1685, cerca de 36 mil pessoas trabalhavam em Versalhes. Para construir e manter tamanho luxo, o rei montou o maior e mais poderoso exército e envolveu-se em inúmeras guerras. Lembrou-nos o Hesíodo de Os trabalhos e os dias que colocou a célebre pergunta: o que faz uma cidade rica: o arado ou a espada? O trabalho no campo ou as guerras e os saques dos despojos dos inimigos? Luiz XIV respondeu. Optou pelo segundo. $\mathrm{O}$ povo pagou. Inclusive com a fome e a peste. Mas o palácio tornou-se o mais belo do mundo e ele se tornou o Rei-Sol e viveu 77 anos, o que para a época era uma eternidade ${ }^{5}$.

Jean Valjean, personagem de Os miseráveis ${ }^{6}$, condenado a dezenove anos de trabalhos forçados por ter furtado um pão, bem que poderia ter sido qualquer infeliz do reinado de Luiz XIV. Obviamente Victor Hugo conhecia bem a história da França e retratava os miseráveis de todos os tempos.

A França no século de Luiz XIV possuía aproximadamente 20 milhões de habitantes, sendo que pelo menos dois terços da população na zona rural em pequenos vilarejos. A sociedade estava distribuída em três estamentos: o clero, dividido em alto e baixo clero; a nobreza, tendo como base a posse de terras e a compra de cargos públicos; no terceiro estado se encontrava o restante da população, inclusive os professores. O que caracterizava os pobres não era somente o fatal desconforto, mas a impossibilidade de projetar qualquer futuro. Pelo menos um terço da população do terceiro estado vivia em situação de miséria, resultando na grande quantidade de mendicantes, principalmente as crianças. As paróquias possuíam o cadastro dos pobres; dessa maneira, a realeza destinava algum auxílio para minimizar a desgraça. A maioria das crianças não frequentava as escolas, pois poucas eram gratuitas e as famílias necessitavam das suas mãos e dos seus braços para o próprio sustento. Em 1698 houve uma lei tornando obrigatória a escolarização até os 14 anos, mas mesmo assim muitas famílias não sentiam a necessidade de escola. Esse foi um dos desafios enfrentados por La Salle e os Irmãos: tornar a escola útil para a vida e atrativa para as crianças (POUTET; PUNGIER, 2001).

No período em que La Salle viveu, a França havia participado de diversas guerras e continuava em conflito com diversos países, trazendo como consequência a devastação da economia e da ordem no país. O país estava mergulhado em miséria e pobreza, e as guerras causaram muitas mortes, deixando mutilados, viúvas e órfãos. Nesse período surgiram diversas congregações religiosas com a finalidade específica de assistir à saúde da população, internatos para cuidar dos órfãos, e pequenas escolas para cuidar da instrução dos meninos e meninas (JUSTO, 2003; POUTET, 2001).

A educação e a organização escolar estavam voltadas para o ensino dos mestres calígrafos que dispunham de um sistema exclusivo no sentido de ensinar um número restrito de crianças mediante ensino pago. Existiam algumas escolas paroquiais e de caridade vinculadas à Igreja Católica, mas sem nenhuma organização curricular ou critérios que pudessem estabelecer uma ordem mínima que favorecesse a aprendizagem. 
La Salle e os primeiros Irmãos, ao instituírem a escola gratuita, não apresentaram nenhuma novidade no que se refere à gratuidade, pois, no século XVII, existiam instituições religiosas que ofereciam o acesso à escola gratuita para os pobres. A novidade das escolas lassalistas estava na instalação de escolas gratuitas para todos os alunos, sem distinção de classe social. Era uma novidade pobres e ricos estudarem juntos. Essa decisão de acolher pobres e ricos na mesma escola foi uma carga muito penosa que La Salle e os primeiros Irmãos tiveram que enfrentar, praticamente durante toda a vida de La Salle, pois, por conta do acesso de todas as crianças às escolas paroquiais lassalistas, houve descontentamento, principalmente dos Mestres Calígrafos, e também dos párocos, que financiavam a abertura e manutenção de escolas em suas paróquias. As paróquias possuíam um catálogo das crianças pobres, e os Irmãos Lassalistas criaram o próprio critério de seleção dos alunos. Importante lembrar que se vivia numa época em que o bispo e teólogo francês, Jacques Bossuet (1627-1704) ${ }^{7}$, fundamentava a origem divina do poder da monarquia nas sagradas escrituras, justificando que Deus delegava aos monarcas, para manter a ordem e a felicidade de um maior número de súditos, uma autoridade sem limites e incontestável. Nos tempos desse jusnaturalismo de origem divina era mais fácil entender que não se podiam misturar aqueles que Deus havia criado para viverem separados. Era a ordo ordinum, a ordem natural das coisas.

\section{Trajetória pessoal}

João Batista de La Salle nasceu no dia 30 de abril de 1651em Reims, França. Era o primogênito de dez irmãos, sendo que quatro faleceram em seus primeiros anos de vida. Cursou Filosofia entre 1667 e 1669, ano em que iniciou a Teologia. Desde os onze anos exercia atividades eclesiásticas na catedral de Reims. Com quinze anos recebeu a função de cônego. João Batista de La Salle era membro do capítulo catedralício e o canonicato era concebido como um privilégio na catedral. Os deveres de um cônego eram relacionados com a oração pública, principalmente o canto diário no coro da catedral da liturgia das horas $^{8}$ e a celebração Eucarística. Os cônegos possuíam um posto de honra nas solenidades litúrgicas e procissões. Além dos ofícios litúrgicos havia reuniões regulares do capítulo para tratar de assuntos internos. O posto de cônego tinha recompensas; a cada cônego era atribuída uma casa contigua à catedral. Se o cônego não a ocupava, como foi o caso de La Salle, poderia alugar. Havia um estipêndio fixo pela participação durante o ano nos serviços litúrgicos. Os regulamentos do capítulo impunham uma disciplina rígida aos cônegos jovens que não eram sacerdotes; os cônegos que seguiam na universidade estavam estritamente sujeitos a longos ofícios litúrgicos, que ocupavam a maior parte do dia, nos domingos e festas (SALM, 2004, p. 38). 


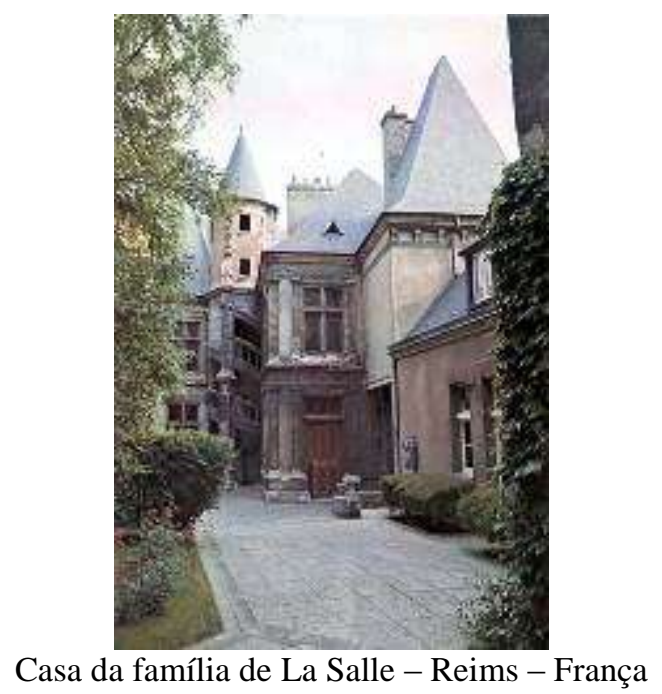

La Salle ingressou no seminário de São Sulpício, em Paris, no ano de 1669 e continuou os estudos de Teologia na Sorbone. Em 1671 faleceu sua mãe e em 1672 faleceu seu pai. Com isso, foi obrigado a interromper os estudos em Paris e retornar a Reims para assumir a tutoria de seus irmãos menores. Retomou os estudos de Teologia na Sorbone em 1673, e em 1675 obteve o bacharelado e em 1680 o doutorado em Teologia.

Em 1679 recebeu a visita do Sr. Adrien Nyel e com ele uma carta da Sra. Maillefer, parente de La Salle. Na carta constava o pedido para que ele, com a ajuda do Sr. Nyel, abrisse uma escola de caridade para as crianças. A primeira escola foi aberta na paróquia de São Maurício, Reims, em 1679 e custeada pela Sra. Maillefer. A escola funcionou bem e obteve sucesso, o que motivou outra senhora a custear as despesas de uma escola na paróquia de São Tiago. Até aquele momento La Salle tinha como projeto de vida seguir o sacerdócio, como pároco e cônego da catedral de Reims. Mas o Sr. Nyel aos poucos foi menos dedicado e os professores contratados não apresentavam qualificação suficiente para atender de maneira eficaz os propósitos das escolas. La Salle alugou uma casa, próxima à sua, para os mestres morarem e assim poder acompanhá-los mais de perto. Ao longo do ano de 1680 La Salle permitiu que os mestres fizessem as refeições em sua casa juntamente com sua família. Por conta disso, houve vários conflitos com seus familiares, pois os mestres não possuíam as boas maneiras e nem o refinamento exigido pela burguesia francesa. No mesmo ano de 1680 La Salle abriu mais uma escola na paróquia de São Sinforiano, contratando mais dois professores, somando, então sete mestres. Devido à nova realidade, estilo de vida e pouca aptidão para o trabalho, alguns mestre abandonaram a empreitada e foram logo substituídos. Em 1682 foi aberta mais uma escola, em Rethel, próximo de Reims; La Salle alugou uma casa e foi morar com os mestres. No mesmo ano, ele abriu mais uma escola que funcionou por pouco tempo. Nesse período ele percebeu a necessidade de organizar o modo de vida dos mestres. Por isso, tomaram a decisão de adotar exercícios comuns diários e se chamaram Irmãos. Nesse período havia muita inquietação por parte dos mestres a respeito do futuro do grupo e das escolas. La Salle consultou várias pessoas de sua confiança e decidiu renunciar ao canonicato e aos poucos foi se desfazendo de seus bens, e com isso, passou a conviver e trabalhar a maior parte do tempo com os mestres. 


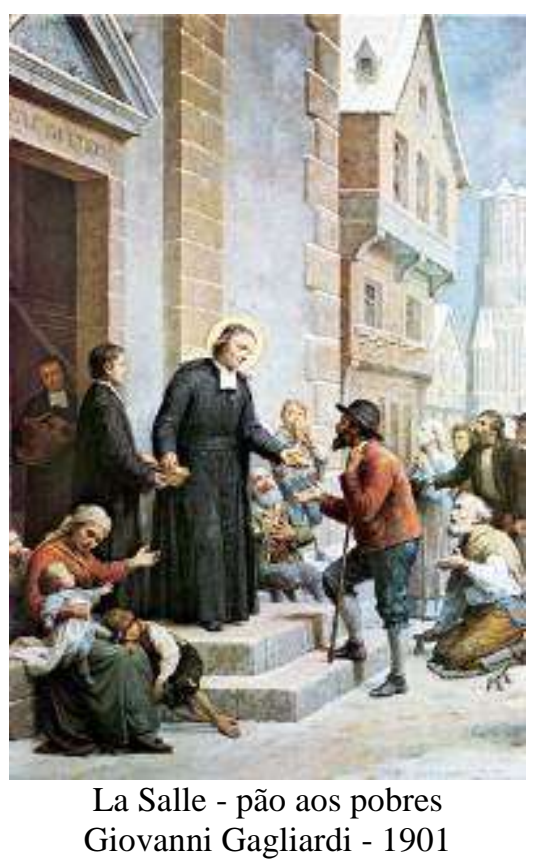

Em 1684, por ocasião das férias escolares, os Irmãos tiveram tempo adequado de reflexão e assumiram a denominação de Irmãos das Escolas Cristãs. Para distinguirem-se dos sacerdotes, adotaram hábito próprio e regulamentaram a vida cotidiana e prática. Havia várias propostas de abertura de escolas, mas o que impedia a expansão do empreendimento era a pouca qualificação dos mestres. Para resolver esse problema, em 1685 La Salle iniciou com os mestres a preparação e ensino de técnicas para a docência. Certamente aqui reside uma das grandes contribuições de La Salle: a criação de uma escola de preparação de professores primários. Nascia a Escola Normal, o Curso de Magistério.

Em 1686 La Salle e os principais Irmãos das sete escolas fizeram uma assembleia e decidiram fazer o voto de obediência por três anos com renovação anual. Com esse compromisso a instituição se tornava mais consistente e o bom andamento das escolas era perceptível. No mesmo ano, La Salle e os Irmãos abriram um noviciado para a formação de novos Irmãos com o objetivo de maior qualificação e perseverança na decisão de vida. No ano de 1690 os Irmãos abriram uma escola em Paris, o que causou vários ataques por parte de mestres de outras escolas que cobravam anuidades. Esses embargaram sua escola confiscando todos os materiais. Viram nas escolas gratuitas dos Irmãos uma concorrência desleal, além do que tiravam das ruas a mão de obra barata das crianças pobres. Após duas sentenças, o tribunal deu ganho de causa aos Irmãos e a escola foi reaberta. As escolas dos Irmãos eram gratuitas e os alunos rapidamente migraram das escolas pagas para as escolas gratuitas. A questão da gratuidade das escolas para todos os meninos de todas as classes sociais é uma disputa demasiado longa e foi discutida ao longo dos séculos XVII ao XIX, o que abriu a possibilidade da universalização da escolarização no ensino público e gratuito. 


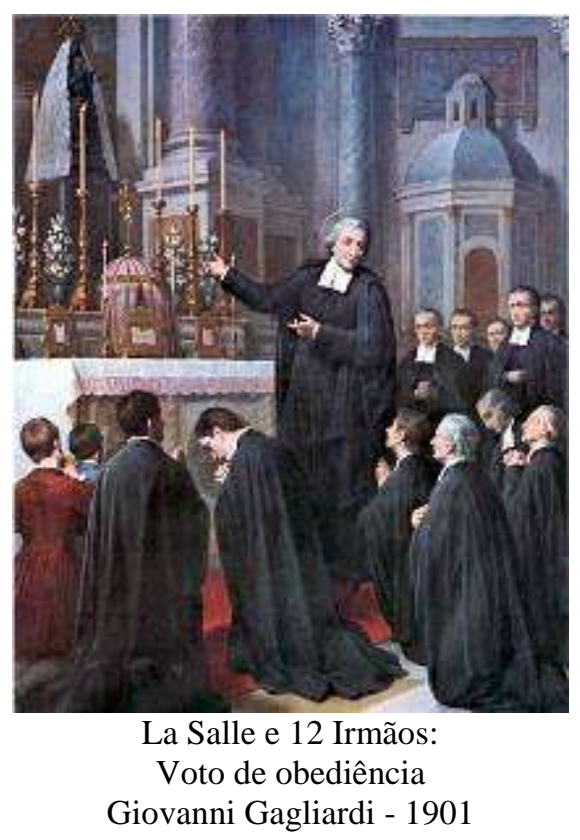

Em 1694 foram aprovadas as Regras Comuns que regiam a vida dos Irmãos nos quesitos canônicos, trabalho e vida em comum. No mesmo período, 12 Irmãos, juntamente com La Salle, fizeram os votos perpétuos ${ }^{9}$ de associação, obediência e estabilidade. Na ocasião, elegeram La Salle como Superior do Instituto e ficou registrado em ata que esta seria a única vez que seria eleito um sacerdote como Superior e nas próximas eleições seriam eleitos somente os Irmãos. Com essa decisão, afastaram as tentativas de padres e bispos que queriam assumir a direção, pois La Salle era o único sacerdote na ordem dos Irmãos. Nesse período o Instituto passava por um momento fecundo e surgiram diversas novas escolas em várias cidades da França e foram produzidos vários subsídios e documentos que fundamentavam as práticas pedagógicas; entre eles estava em elaboração o Guia das Escolas Cristãs.

Nos anos de 1702 a 1704 La Salle publicou diversos manuais pedagógicos e catequéticos. Dentre os livros principais estavam as Regras do Decoro e da Urbanidade Cristãos, traduzidas para a língua portuguesa e publicadas em 2012 pela Unilasalle Editora. Foi um livro escrito para o uso curricular dos alunos a partir do oitavo nível, e escrito em letra gótica que apresentava dificuldade maior na leitura. $\mathrm{O}$ objetivo também do livro era ser um instrumento formativo com regras de urbanidade e muito útil para os meninos pobres em sua inserção na vida social. A preocupação era de que os meninos não fossem estranhos ao mundo e adquirissem a refinada educação de decoro e urbanidade. Até 1719 foram publicadas cinco edições e várias outras edições paralelas e resumidas foram impressas, o que de fato se tornou uma obra de grande valor para sociedade em geral. A obra teve 171 edições de exemplares controlados e diversas edições fora da França. Existiram também diversas impressões resumidas e paralelas sem fazer menção e referência ao autor La Salle.

La Salle em sua trajetória sofreu diversas perseguições e processos judiciais. Houve, no decorrer de seu trabalho na fundação e coordenação das escolas cristãs, conflitos com as autoridades clericais, pois, o fato de o Instituto dos Irmãos das Escolas Cristãs ser formado unicamente por homens leigos e sem aspiração ao sacerdócio intrigou padres, bispos e cardeais. Com isso, foi o primeiro Instituto formado exclusivamente por homens leigos consagrados, um passo importante para a consolidação da instituição e dedicação exclusiva no cuidado e manutenção das escolas. Diversos grupos de professores, como os mestres 
calígrafos e os mestres das "pequenas escolas", sentiram que seu negócio educacional foi ameaçado por diversas vezes em vários locais pelas escolas do Instituto dos Irmãos das Escolas Cristãs, e isso gerou atrito pessoal e denúncias contra os Irmãos. O ano de 1704 foi bastante penoso para La Salle porque teve que se defender nos tribunais de diversas acusações, sendo condenado a pagar valores altos e proibido de continuar com as escolas de Paris, levando os Irmãos a abandonar várias delas. Esse período de processo e condenações se arrastou até 1706. Em alguns casos até havia aceitação da presença dos Irmãos no trabalho das escolas, desde que aceitassem somente alunos pobres e com o certificado de pobreza. La Salle concebia a escola aberta e acessível a todos os meninos e por isso não concordou com a situação discriminatória e excludente. É importante frisar que todas as escolas eram financiadas e havia garantia dos párocos de condições necessárias para o funcionamento das escolas. As escolas estavam estritamente ligadas à Igreja e faziam parte do currículo escolar as atividades religiosas. Entre 1706 e 1710 foram abertas várias outras escolas, até no Sul da França. De 1679 a 1719, ano do falecimento de La Salle, o Instituto havia implantado 49 escolas, embora nem todas tenham prosperado, mas o fundador deixou a instituição com mais de 20 escolas e aproximadamente 100 Irmãos.

Os últimos anos de vida de La Salle foram bem conturbados, com situações de crise pessoal. Nesse período, entre 1710 e 1719, o Instituto estava consolidado, com a identidade firme de escolas gratuitas, grande avanço para a época, e os Irmãos assumiram a identidade de consagrados leigos, ou seja, o Instituto estava fora da hierarquia clerical, outra enorme conquista. Dentre os conflitos estava o fato de apenas ele ter vivenciado todos os períodos de vida do Instituto, enquanto poucos Irmãos tinham uma caminhada com tantos anos dedicados à instrução das crianças e vida de comunidade. Faltava, portanto, aos outros, a experiência e os conhecimentos do fundador.

Nas grandes decisões do Instituto era importante considerar a experiência e história dos Irmãos, pois haviam prometido e feito votos de permanecer em Sociedade para manter juntos e por associação as escolas gratuitas. Porém La Salle não estava seguro de que todos tinham consciência da novidade radical instaurada na Igreja pelo seu modo de viver como religiosos e na missão específica do Instituto de educar os meninos gratuitamente. Diante desses fatos, La Salle se refugiou em Grenoble, num vilarejo chamado Parmênia, sul da França. Com idade avançada, considerado bastante idoso para a época, com mais de 60 anos, avaliou todos os percursos traçados pelo Instituto e a quantidade de pessoas envolvidas; estava ciente de que muitos haviam abandonado, foi perseguido por eclesiásticos e grupos corporativos, questionou-se se não havia errado ao longo do caminho e se não tinha fracassado na empreitada de conduzir um grupo de Irmãos e a administração das escolas. Permaneceu um tempo em uma ermida na Parmêmia e estava determinado a seguir a vida eremítica até o final de seus dias, pois, após uma vida agitada, a solidão e o silêncio o atraíam muito. Nesse período de três anos, La Salle deu-se conta de que o Instituto era formado por Irmãos de diferentes culturas, idades e mentalidades, e isso enriquecia sempre a vida em comunidade e a missão educativa. Percebeu e aceitou que o Instituto não é era um bem seu, mas uma obra da Igreja e com a finalidade de salvação e instrução dos meninos, e com isso, aprendeu a viver sem o apego ao Instituto ${ }^{10}$.

Em abril de 1714 os Irmãos de Paris enviam uma carta a La Salle solicitando seu retorno imediato ao Instituto recordando-lhe os compromissos assumidos nos votos religiosos de permanecer em sociedade, e a obediência. Ele a Paris e assume a função de animar a vida das comunidades e do Instituto, e os Irmãos percebem que as Escolas Cristãs são o ministério de salvação integrado na vida da Igreja. La Salle faleceu em 07 de abril de 1719. 
La Salle escreveu muitas obras em resposta às necessidades das escolas e dos Irmãos. Há uma lacuna muito grande sobre a obra educacional de La Salle na bibliografia e mesmo nas dissertações e teses nos Programas de Educação no Brasil. Conscientes disso, apresentamos, no Programa de Pós-Graduação em Educação, na Universidade Federal de São Carlos, no primeiro semestre de 2013, uma disciplina, em que foram estudados autores e textos que serviram de fundamentos à educação católica e, por sua vez, marcaram indelevelmente, a escola moderna:

1. De magistro, de Tomás de Aquino ${ }^{11 ' ;}$

2. Ratio studiorum, Jesuítas;

3. Guia das escolas cristãs, João Baptista de La Salle;

4. Guia das escolas, Marcelino Champagnat (Maristas);

5. Formação de padres nos seminários menores tridentinos.

Há uma bibliografia abundante sobre a escolástica tomista e sobre a pedagogia jesuítica. Os jesuítas sempre tiveram o grande mérito de registrar e divulgar tudo. Em língua portuguesa, a grande obra sobre os jesuítas é a História da Companhia de Jesus no Brasil, em dez tomos, de autoria de Serafim Leite, publicada entre o final da década de 1930 e o fim de 1940. Mas há um silêncio sobre La Salle, sobre os Maristas e sobre aqueles que formaram grande parte dos formadores: os padres ${ }^{12}$.

Em relação aos lassalistas, no Brasil, essa lacuna começa a ser preenchida. O Irmão Edgard Hengemüle organizou a publicação, em 2012, em Língua Portuguesa, pela Unilasalle Editora, as Obras Completas de São João Batista de La Salle ${ }^{13}$, em seis volumes. As obras estão distribuídas em quatro seções:

1) Escritos pessoais e históricos: Memórias dos Começos; Memória sobre o Hábito; Memória em favor da Leitura em Francês; Voto Heroico; Fórmula de Votos; Regras que me impus; Testamento; Cartas.

2) Escritos ascéticos e espirituais: Regras Comuns dos Irmãos das Escolas Cristãs; Regra do Irmão Diretor; Coleção de Vários Pequenos Tratados; Prefácio (a um Pequeno Tratado); Diretórios; Explicação do Método de Oração Mental; Meditações (Para todos os Domingos do Ano; Sobre as principais Festas do Ano; Adicionais; Para o Tempo de Retiro).

3) Escritos Pedagógicos: Guia das Escolas Cristãs; Regras do Decoro e da Urbanidade Cristãos; Exercícios de Piedade feitos ao longo do dia nas Escolas Cristãs.

4) Escritos Catequéticos: Deveres do Cristão para com Deus I, II e III; Compêndio Maior dos Deveres do Cristão; Compêndio Menor dos Deveres do Cristão; Instruções e Orações para a Santa Missa, a Confissão e a Comunhão; Cânticos Espirituais.

Em 1900 a Igreja o proclamou Santo. Em 1950 a Igreja o proclamou Padroeiro de todos os Professores por haver dedicado sua vida à educação, contribuído com a formação dos mestres pela criação de escola própria para essa finalidade, elevado o conceito da profissão de professor e criado um Instituto dedicado exclusivamente à educação. 


\section{Contexto do surgimento do Guia das Escolas}

Em geral, as escolas para crianças na França, no tempo de La Salle, eram pagas e administradas por mestres de maneira individual. Geralmente tinham um só professor, um grupo de alunos e uma só classe. Os mestres eram pagos e ensinavam a doutrina cristã, ler, escrever e aritmética. Atendiam a um número de aproximadamente 10 alunos. No currículo estava estabelecido o ensino de leitura em latim e escrita. As escolas menores ensinavam a ler e escrever aos meninos menores. Existiam os colégios, com organização, hierarquia, ordem e espaço físico avantajado. Os mestres calígrafos dispunham de escolas pagas, com ensino individualizado, destinado à caligrafia e à leitura. As escolas gratuitas tinham vínculo a Igreja, mantidas por "caridade", pelas paróquias e ordens religiosas.

Pelo fato de existirem diversas escolas de vários níveis e tamanhos, existiam diversos problemas conforme descreve Lauraire:

Los autores resumen bien en algunas frases los ingredientes ordinarios de una escuela menor del siglo XVII: desorden aparente, método individual, recurso a los castigos corporales, mezcla de edades (NB: el carácter mixto era más raro), falta de organización del espacio-aula, relación pedagógica singular y no colectiva, ausencia de normas claramente establecidas sobre el comportamiento esperado de los alumnos, sanciones-sorpresas, riesgo de parcialidad de parte del maestro, inexistencia de una clase-grupo" (LAURAIRE, 2006, p. 28).

Ordem e silêncio são elementos indispensáveis na aula. Ora, o método de ensino mais difundido nas escolas primárias não favorecia nem a ordem, nem o silêncio, nem o aproveitamento do tempo. O professor chamava junto a si aluno por aluno: a cada um, individualmente, ia repetindo a lição, enquanto os outros passavam o tempo brincando, brigando, e quase nunca estudando a lição. Poder-se-ia esperar outra coisa de crianças? Ademais, comprimiam-se em locais mal adaptados e extremamente exíguos. O célebre tratado L'Escole Paroissiale, publicado em Paris em 1654, prevê uma sala de apenas 8 por $6 \mathrm{~m}$ para 100 alunos (JUSTO, 2003, p. 229).

La Salle prescreve no Guia das Escolas Cristãs nove meios para estabelecer e manter a ordem nas escolas: a vigilância que o mestre deve exercer na escola; os sinais utilizados nas Escolas Cristãs; os catálogos; as recompensas; as correções; a assiduidade dos alunos e sua pontualidade; a regulamentação dos dias de folga; o estabelecimento de diversas responsabilidades e a finalidade em cumprir bem seus empregos; a estrutura, $a$ qualidade e a uniformidade das escolas e dos móveis adequados a elas. Percebe-se que, para ele, não é possível educar sem condições adequadas, seja para ricos, seja para pobres. Os mestres precisam de boas condições para organizar o ensino. "Organização" será uma palavra chave no Guia das Escolas. Segundo a tese que defendemos neste ensaio, foi La Salle quem fundou a organização minuciosa dos tempos e espaços escolares que se repete até os dias de hoje nas escolas.

\section{Guia das Escolas Cristãs}

O Guia das Escolas Cristãs ${ }^{14}$, ou simplesmente Guia, foi publicado pela primeira vez em 1720, como se pode ver na cópia acima. Existe um manuscrito na Biblioteca de Paris com a data de 1706, o que leva a afirmar sobre o uso do documento, mesmo sem ter publicação oficial antes dessa data. Tratava-se de um manual pedagógico e administrativo 
que regia a maneira de conduzir as classes e a forma de gerir as escolas do Instituto dos Irmãos das Escolas Cristãs. O objetivo do Guia era assegurar a unidade em todas as escolas lassalistas, de tal maneira que os procedimentos administrativos e a organização pedagógica eram os mesmos em todas elas. No ano de 2012 foi publicado em língua portuguesa o Guia das Escolas Cristãs pela Unilasalle Editora. Fato importante para todos os lassalistas, educadores e pesquisadores, pois, agora, o Guia esta acessível a todos. Até era possível o acesso ao Guia em outras línguas e era um documento raro, encontrado em algumas escolas lassalistas e algumas traduções não oficiais.

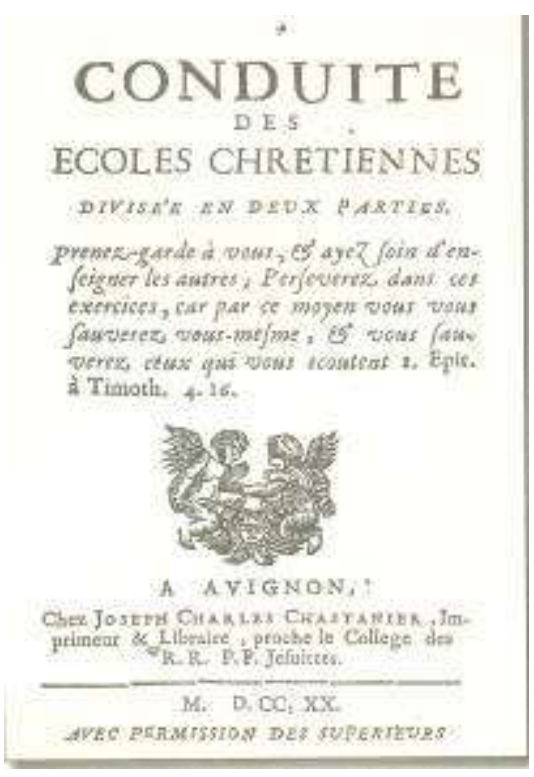

No prefácio do Guia fica evidenciada a autoria do documento:

Este Guia só foi redigido em forma de regulamento após numerosas trocas de ideias entre os Irmãos mais antigos deste Instituto e os mais aptos em dar aula, e após experiência de vários anos. Nada foi nele introduzido que não fosse muito consensual e bem comprovado, de que não tivessem ponderado as vantagens e inconvenientes e previsto, tanto quanto possível, as boas e más consequências (LA SALLE, 2012b, p. 19).

La Salle foi o organizador e sistematizador do Guia, os Irmãos contribuíram com suas experiências de professores e diretores. Foi um documento elaborado ao longo do tempo após vários anos de trabalho, e passou a ser um instrumento de estudos dos Irmãos na formação inicial e nos processos de formação continuada.

O Guia foi sistematizado após vinte e cinco anos de fundação da primeira escola lassalista e para a época um quarto de século representava quase a expectativa de vida da população. Nesses vinte e cinco anos até a elaboração do primeiro manuscrito do Guia, muitos Irmãos passaram pelo Instituto, vários faleceram e outros tantos deixaram a obra. Isso significa que o Guia representa a construção pedagógica do Instituto e expressa claramente os princípios pedagógicos e métodos de ensino lassalista. Durante esse período, mesmo sem o Guia sistematizado, as escolas e os Irmãos não atuavam de qualquer jeito, pois, em 1694 foram aprovadas as Regras Comuns dos Irmãos das Escolas Cristãs (obra traduzida e publicada na língua portuguesa em 2012 pela Unilasalle Editora) que 
apresentavam as normas e diretrizes do Instituto. É possível perceber a preocupação de La Salle desde o princípio em melhorar o modo de vida e a qualidade profissional dos mestres.

O Guia foi escrito pelos Irmãos e para os Irmãos a fim de proporcionar ensino de qualidade aos filhos dos artesãos e aos pobres. Os Irmãos experimentaram vários métodos, procedimentos didáticos, disciplina, organização da escola e diversos meios educativos até encontrar a forma apropriada. A construção do Guia teve a participação de todos os mestres que doaram sua vida em prol da educação, contribuíram com sua experiência e conjuntamente estabeleceram o que poderia ser conservado e o que deveria ser deixado de lado. Esse modo de trabalhar e de construir o Guia foi um processo indutivo (LAURAIRE, 2006). O primeiro passo foi tomar consciência da realidade, e assim, conhecer as necessidades educativas dos alunos, bem como as condições de vida e suas dificuldades. A partir dessa análise se estabeleceram as modalidades mais adequadas de ensino. Criou-se assim uma escola inserida na realidade dos alunos e se ensinaram conteúdos para lidar com as situações concretas e reais da vida.

É importante ressaltar que o Guia trata somente das escolas primárias do Instituto dos Irmãos das Escolas Cristãs. As iniciativas pedagógicas de La Salle não se limitaram unicamente ao modelo do Guia. Por conta dos pedidos, necessidades e circunstâncias, La Salle criou um curso provisório de formação para jovens irlandeses, Escolas dominicais para jovens aprendizes e trabalhadores e o Seminário de formação de mestres para as escolas rurais.

O Guia das Escolas Cristãs é organizado da seguinte maneira conforme foi descrito no Prefácio:

Este Guia divide-se em três partes. Na primeira, são tratadas as atividades da escola e o que se faz nela desde a entrada até a saída. A segunda expõe os meios necessários e úteis, dos quais os mestres devem servir-se para estabelecer e manter a ordem nela. A terceira trata, primeiro, dos deveres do Inspetor das Escolas; segundo, do cuidado e empenho que deve ter o formador dos novos mestres; terceiro, das qualidades que os mestres deverão possuir ou adquirir, da conduta que devem ter para desempenharem bem as obrigações escolares; quarto, dos deveres dos alunos (LA SALLE, 2012b, p. 20).

A primeira parte do Guia apresenta 11 capítulos, assim distribuídos:

1. Da entrada na escola e do início das aulas;

2. Do desjejum e da merenda;

3. Das lições;

4. Da escrita;

5. Da aritmética;

6. Da ortografia;

7. Das orações;

8. Da santa Missa;

9. Do catecismo;

10. Dos cânticos;

11. Da saída dos alunos. 
A segunda parte do Guia apresenta nove capítulos:

1. Da vigilância que o mestre deve exercer na escola;

2. Dos sinais utilizados nas Escolas Cristãs;

3. Dos catálogos;

4. Das recompensas;

5. Das correções em geral;

6. Das ausências;

7. Dos feriados;

8. Dos oficiais da escola;

9. Da estrutura, da uniformidade das escolas e dos móveis adequados a elas.

A terceira parte do Guia é organizada em cinco capítulos:

1. Deveres do Inspetor das escolas;

2. Da supervisão do Inspetor das escolas;

3. Da admissão dos alunos;

4. Da distribuição dos alunos nas salas de aula;

5. Da promoção dos alunos de uma lição a outra.

O Guia prescreve um capítulo sobre a formação dos novos mestres, regra do mestre dos internos e dos diferentes tipos de casa do Instituto.

Na primeira parte do Guia aparecem descritos os elementos didáticos e curriculares das escolas. As portas da escola se abriam às sete e meia, e às treze horas. Os alunos adentravam nas classes e em seguida se punham a estudar individualmente, aguardavam o início das aulas e o trabalho coletivo em ambiente calmo era propício à aprendizagem, sempre na presença do mestre. Havia o cuidado de ter a quantidade de alunos de acordo com a capacidade do mestre e esses vigiavam para que nenhum aluno chegasse atrasado. $\mathrm{O}$ desjejum era feito na classe para que os alunos adquirissem os hábitos necessários. Durante o desjejum era feita a coleta para os mais pobres e cabia ao mestre verificar quem de fato era pobre e necessitava; havia os alunos encarregados de fazer a coleta. Em seguida começavam as atividades pedagógicas, organizadas em lições.

O Guia prescreve nove espécies de lições:

1. O cartaz do alfabeto;

2. O cartaz das sílabas;

3. O silabário;

4. O primeiro livro;

5. O segundo livro, no qual os que souberem silabar perfeitamente começam a ler;

6. O terceiro livro, que serve para aprender a ler por pausas;

7. O saltério;

8. A Urbanidade;

9. Os manuscritos.

A organização dos alunos é assim prescrita no Guia: "Todos os alunos, de todas as lições, exceto os que leem nos cartazes, serão distribuídos em três ordens: a primeira, dos principiantes; a segunda, dos médios; e a terceira, dos avançados e dos perfeitos nesta lição" (LA SALLE, 2012b, p. 36). 
A escrita somente era ensinada aos alunos após lerem perfeitamente em francês e latim. Porém, o Guia prescreve uma exceção, caso o aluno tivesse atingido 12 anos e ainda não soubesse o latim, poderia começar a escrever. Os objetos específicos usados na escrita eram: papel, penas e canivete, tinta, modelos, transparências e mata-borrão. Eram destinadas duas horas por dia para a escrita, sendo uma hora pela manhã e uma hora à tarde. Havia oito ordens de escreventes em letra redonda, diferentes umas das outras. Cabia ao mestre verificar em qual ordem de escrita estava cada aluno, qual momento adequado para avançar de ordem e ensinar adequadamente conforme a prescrição do Guia para cada ordem.

A aritmética era ensinada duas vezes por semana, sendo meia hora cada dia. Havia em cada classe um quadro contendo dois painéis, destinado para os exercícios de aritmética. Havia alunos em diferentes níveis e, por isso, o mestre precisava ter o cuidado necessário para escrever no quadro uma operação de cada lição. Somente ensinava aritmética aos alunos que estavam em nível médio da escrita. Cada aluno realizava as operações no quadro e o mestre acompanhava o processo. Os alunos que ainda não estavam avançados na escrita acompanhavam atentamente o trabalho desenvolvido pelos outros colegas.

A Segunda parte do Guia descreve os meios para estabelecer e manter a ordem nas escolas. Nessa parte, transparece a grande preocupação de La Salle para que as escolas funcionassem bem. Essa preocupação é explicitada nos escritos de La Salle. "Tenha cuidado para que a escola funcione sempre bem"(La Salle, 2012a, p. 159. Carta 57, escrita ao Irmão Roberto em 26 de fevereiro de 1709). "Estou muito feliz por sua escola ir bem e você estar com suficientes crianças. Tenha cuidado de instruí-las bem”(La Salle, 2012b, p. 161. Carta 58, escrita ao Irmão Roberto em 26 de abril de 1709). La Salle tinha consciência de que a escola era a oportunidade única para os meninos pobres e os pais esperavam uma escola eficaz. A organização do Guia de maneira minuciosa e detalhista é justificada porque o ensino simultâneo estava nos primeiros passos na instauração da ordem das classes. Havia a preocupação e necessidade de estabelecer a disciplina em benefício do grupo, pois com isso, os alunos podiam experimentar os valores sociais importantes que motivavam seu comportamento adequado com os padrões sociais. Um dos pontos que distinguia as Escolas Lassalistas das tantas outras escolas era o estabelecimento de uma relação educativa intensa e personalizada com os alunos e sua família.

A maneira de ensinar era primordial e havia grande empenho dos Irmãos em convencer os pais sobre a importância dos artesãos em saber ler e escrever. Por isso, o Irmão deveria dominar o conteúdo que ensinava. Para que isso funcionasse adequadamente, a organização da formação acadêmica e espiritual não estava dissociada, de tal maneira que ao longo do dia quando não estavam na classe os Irmãos continuavam sua formação.

A Terceira parte do Guia trata dos deveres do Inspetor das escolas. Os Inspetores tinham as seguintes atribuições: "1. Na supervisão que deve exercer sobre as escolas, os mestre e os alunos; 2. Em distribuir os alunos nas classes e em indicar-lhes a lição; 3. Em promovê-los, quando capazes, a uma lição mais adiantada" (La Salle, 2012b, p. 243). Cabia ao Inspetor fazer a vigilância sobre os alunos e assegurar que tivessem idade adequada para ingressar na escola, com saúde e bem asseados. O Inspetor estava atento para que nada contrário à ordem ocorresse e pudesse atrapalhar o trabalho do mestre, inclusive, vigiava para que não houvesse indisciplina e caso ocorresse tomava as providências necessárias. 
Um ponto importante prescrito no Guia e que foi a garantia de sucesso e expansão das escolas lassalistas foi a boa formação do mestre. O Guia apresenta vinte páginas com instruções e critérios para a seleção e formação dos mestres. "A formação dos novos mestres consiste em duas coisas: 1. Eliminar nos novos mestres o que eles têm e que não deviam ter; 2. Fazer-lhes adquirir o que lhes falta e que lhes é muito necessário ter"(La Salle, 2012b, p. 291). O Guia descreve de maneira minuciosa quinze itens que se deve eliminar nos novos mestres:

1. Evitar falar durante um tempo; 2. A agitação; 3. A leviandade; 4. A precipitação; 5 . O rigor e a severidade; 6 . A impaciência; 7. A aversão a alguns; acepção de pessoas; 8. A lentidão; 9. A negligência; 10. A frouxidão; 11. O desânimo fácil; 12. A familiaridade; 13. As preferências e amizades particulares; 14. O espírito de improvisação; 15. Exterior desconcentrado, avoado, ou pregado, fixo nalgum ponto. (LA SALLE, 2012b, p. 292ss)

Em seguida, o Guia prescreve as habilidades que os novos mestres devem adquirir e os meios para isso:

1. Coragem; 2. Autoridade e firmeza; 3. Circunspecção: exterior grave, digno e modesto. 4. Vigilância; 5. Atenção sobre si mesmo; 6. Compostura; 7. Prudência; 8. Aspecto animador e atraente. 9. Zelo; 10. Facilidade para falar, expressar-se com clareza, ordem e ao nível dos meninos aos quais se ensina. (LA SALLE, 2012b, p. 302ss).

Esse plano de formação dos mestres visava profissionais eficientes e preparados para as mais diversas situações. La Salle fundou a Escola de Formação de Professores, também chamada de Escola Normal. Nela, eram oferecidos subsídios didáticos e métodos adequados e inovadores. Com toda a estrutura pensada e desenvolvida por La Salle na formação dos mestres, isso contribuiu para elevar o prestígio do magistério, pois, o mestre precisava ser pessoa culta, simpática, moralmente irrepreensível e com dedicação profissional.

O que chamamos hoje de planejamento pedagógico ou de formação permanente do corpo docente, João Batista de La Salle já fazia com o nome de Meditações para os tempos de retiro para todas as pessoas que se dedicam à educação da juventude; $e$ particularmente para o retiro dos Irmãos das Escolas Cristãs durante as férias. Nos tempos de férias os professores estudavam e se preparavam para um novo ano de atividades. Era o início do século XVIII. 


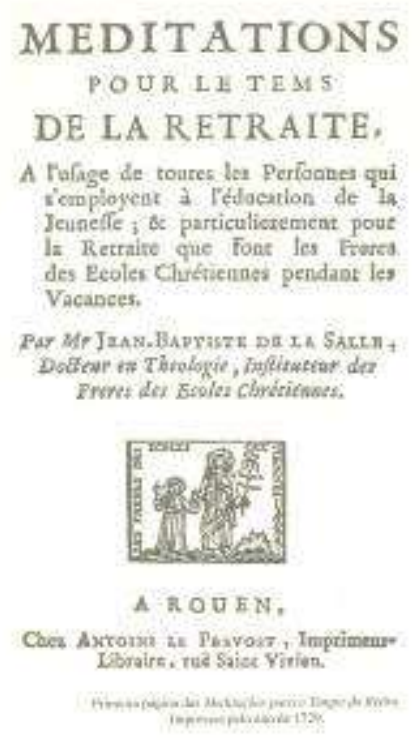

\section{Procedimentos pedagógicos}

Um dos elementos marcantes e que fundamentou o sucesso e continuidade das escolas de La Salle é a ordem, eleita como uma condição essencial do progresso dos alunos e eficiência das escolas. Através da ordem, regulamentação e disciplina, foi possível atingir a finalidade do Instituto dos Irmãos das Escolas Cristãs conforme é apresentado nas Regras Comuns dos Irmãos das Escolas Cristãs.

O fim deste Instituto é dar educação cristã aos meninos; e é com este objetivo que o mesmo dirige as escolas, para que, estando os meninos da manhã à tarde sob a direção dos mestres, estes possam ensinar-lhes a bem viver, instruindo-os nos mistérios de nossa santa religião, inspirando-lhes as máximas cristas, e dando-lhes, assim, a educação que lhes convém (LA SALLE, 2012d, p. 18)

Um dos métodos para combater a indisciplina era a ordem. A ordem evitava que as mudanças de humor dos mestres afetassem sua relação com os alunos, isso protegia os alunos de situações arbitrárias e subjetivismos. A ordem evitava os descuidos, vacilo e agressividade, proporcionando o bom funcionamento da classe e a serenidade do grupo, pois todos sabiam o que fazer, como fazer e quando fazer. Lauraire (2006) enfatiza que a ordem tem uma dimensão benéfica porque proporciona segurança e proteção, para o mestre e para o aluno inseguro e duvidoso. Pode também ser a garantia contra os deslizes e assegura o controle do grupo, pois, é mais fácil prevenir do restabelecer a ordem depois da confusão.

La Salle, no período em que as correções escolares se davam basicamente através do castigo corporal, estabeleceu meios diferenciados para as correções no intuito de suavizar a severa disciplina escolar da época.

De pouco proveito seriam as repreensões e correções se quem as faz não tomasse os meios acertados para serem bem feitas. (...) Os homens e mesmo as crianças são dotados de razão. Por isso, não devem ser 
corrigidos como animais e, sim, como pessoas racionais. Importa repreender as crianças e corrigi-la com justiça, fazendo-lhes ver o mal que fizeram, e o castigo merecido pela falta que cometeram, tentando levá-las a aceitar a correção (LA SALLE, 2013, p. 210).

La Salle instruía os Irmãos através de cartas. Dentre várias recomendações, estava o cuidado quanto à disciplina e sanções aplicadas aos alunos:

(...) cuide para não deixar-se levar pela impaciência na aula. (...) Este é um defeito que há ocasião de se cair. É preciso vigiar muito sobre si para não se deixar levar a ele. Por amor de Deus, não bata nos alunos com a mão. Não é à força de golpes que se atraem as pessoas ao bem nem a Deus. Também nunca faça com a vareta. Quanto à vara, lance mão dela somente quando necessário. Devolva-a depois de a ter usado, para não acontecer empregá-la em seus acessos de impaciência (LA SALLE, 2012a, p. 195).

Conforme demostra Lauraire (2006, p. 28), o método individual, até então empregado nas escolas, gerava situação de indisciplina e desordem. Para combater a indisciplina dos alunos, e isso era uma tradição educativa, eram empregadas medidas disciplinares duras e castigos corporais. Nas escolas menores do século XVII, seguindo o modelo das escolas precedentes, era empregada a aspereza disciplinar nos alunos. Por ser um meio de disciplina reproduzido por séculos e inculcado na cultura escolar, a rigidez e severidade disciplinar não acarretava problema aos pais.

No método simultâneo de ensino, modelo que conhecemos hoje e absolutamente difundido na organização escolar, falava-se pouco e somente o necessário. O professor encaminhava as instruções e os alunos executavam. Para que houvesse educação e instrução adequada, era necessário antes de tudo, um método adequado.

Cada ordem de lição terá o seu lugar determinado na sala, de maneira tal, que os alunos de uma ordem de lição não fiquem mesclados e confundidos com os de outra ordem da mesma lição, como, por exemplo, os iniciantes com os médios. Deverão ser facilmente distinguidos uns dos outros pelo lugar que ocupam. Todos os alunos de todas as três ordens lerão, no entanto, juntos, sem separação e distinção, segundo indicar o mestre (LA SALLE, 2012b, p. 37).

Através do método simultâneo de ensino, era proporcionada a interatividade entre o mestre e os alunos. O método simultâneo de ensino, introduzido por La Salle como o mais eficiente em um projeto educativo visava à escolarização de grande número de alunos e a universalização do ensino. O método simultâneo de ensino proporcionava ao mestre ter a visão de todos os alunos na sala. Com isso, era aplicado o princípio da vigilância. Todas as atividades na escola eram executadas sob a ordem do mestre. Isso será lembrado por Foucault em Vigiar e Punir.

La Salle sistematizou o método simultâneo de ensino preconizado por Comênio na Didactica Magna. Até então, o método simultâneo era aplicado na lição de leitura a um número restrito de alunos. La Salle aplicou o método simultâneo a todas as lições (JUSTO, 2003). 


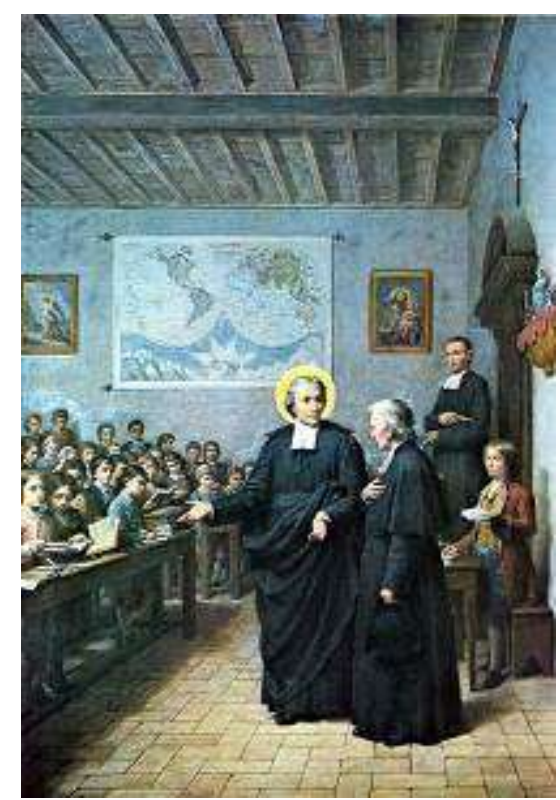

La Salle - Escola em Paris

Giovanni Gagliardi - 1901

A opção de La Salle pelo ensino simultâneo e a presença de vários níveis na classe, necessitou de uma organização distributiva dos alunos. Dessa maneira facilitava a prática de exercícios comuns e o trabalho individual acontecia concomitantemente. Ao mesmo tempo, o mestre mantinha a vigilância sobre toda a classe. $\mathrm{O}$ ensino simultâneo requereu organização rigorosa da classe e de horários comuns, bem como a obrigação de pontualidade e assiduidade dos alunos, e ainda, a distribuição e organização do tempo para a execução das lições e dos exercícios religiosos. (LAURAIRE, 2006).

O método simultâneo com a presença constante do mestre assegurava a continuidade do trabalho e o acompanhamento das atividades dos alunos. La Salle enfatiza que o aluno tem necessidade da presença do mestre pois ele está ainda em processo de aprendizagem e precisa de modelos e exemplos.

O ensino simultâneo exigiu a elaboração de conteúdo curricular que garantia a aprendizagem de todos os alunos da classe. Pela organização de classes, as escolas lassalistas possuíam em média três a quatro salas de aulas, e com isso, era possível organizar as turmas de maneira mais homogênea e distribuir os conteúdos em ordem coerente e progressiva. Por isso, no ingresso dos alunos, existia o cuidado da realização de exames de nível para colocá-los na classe e lição de acordo com o nível de aprendizagem.

Nos séculos XVII e XVIII as crianças eram vistas na sociedade como pequenos adultos e desde cedo precisavam adquirir o comportamento dos mais velhos. Para isso, La Salle é movido por uma sensibilidade importante. "Se tendes para com eles a firmeza de pai para tirá-los e afastá-los do mal, devei ter-lhes também a ternura de mãe para acolhelos e fazer-lhes todo o bem que depende de vós"(LA SALLE, 2013, p. 83). O primeiro pressuposto de La Salle para uma educação eficaz e que faça diferença é "tocar o coração dos alunos". Não é sem motivo que os mestres se chamaram Irmãos, são irmãos entre si e irmãos mais velhos de seus alunos e devem guiá-los com ternura e afeto. 


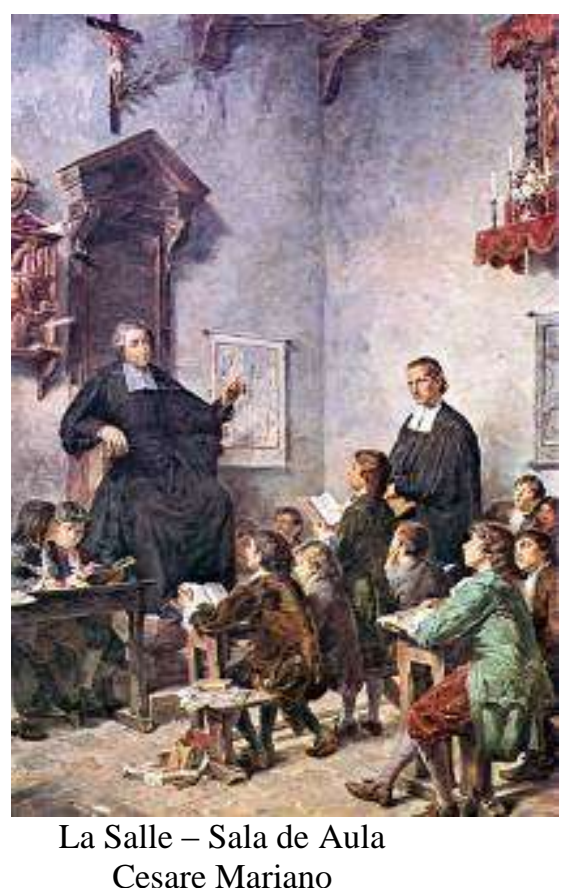

Antes de o aluno ingressar na escola era feita uma verificação para sondar e mapear a realidade familiar, inclusive o nível de pobreza. O objetivo da entrevista com a família era o de conhecer os traços de personalidade do aluno e oferecer um acompanhamento personalizado, e se houvesse a necessidade, um acompanhamento adaptado durante todo o tempo que durasse sua escolaridade. Outro objetivo importante da entrevista e preenchimento do formulário era informar-se sobre os antecedentes escolares do aluno, principalmente para poder avaliar sua capacidade de assiduidade, pontualidade e a seriedade no trabalho escolar. Caso o aluno fosse um adolescente, era importante captar dos pais qual era o projeto que tinham para ele. Na prática, a escolaridade na França no no tempo de La Salle não era obrigatória, apesar de existirem alguns decretos municipais que obrigavam a participação das crianças na escola não havia uma idade determinada para começar a escolarização. Para La Salle, um adolescente tinha aproximadamente 12 anos e nessa idade muitos meninos já estavam trabalhando ou eram aprendizes. Estava claro que um aluno, raras vezes, ficava na escola além dos quatorze anos.

A avaliação do rendimento escolar era constante com o intuito de verificar o nível de aprendizagem dos alunos e atestar se estavam aptos para avançar de nível e lição. Um dos itens para estimular a responsabilidade e a participação, desenvolver aptidões e promover a ordem nas escolas era o estabelecimento de diversas responsabilidades para os alunos. Nas escolas existiam diferentes funções que o professor não poderia e não deveria fazer por ele mesmo. O Guia das Escolas Cristãs prescreve quatorze serviços que os alunos executavam: o recitador de orações; o ministro da santa Missa; o esmoler; O portaaspersório; o porta-terços; o sineiro; o inspetor e o vigilante; o primeiro dos bancos; o visitante dos ausentes; o distribuidor e coletor das folhas; o distribuidor e coletor de livros; o varredor; o porteiro; o chaveiro (LA SALLE, 2012b).

La Salle prestigiou a língua vernácula e prescreveu a alfabetização dos alunos na língua materna, no caso, a francesa, não a latina, conforme os colégios da época ensinavam e era usual por força da organização eclesiástica da sociedade. Os Oratorianos e as escolas de Port-Royal, as principais, já utilizam a alfabetização na língua francesa, porém, com pouca influência na estrutura do sistema educativo francês. 
As principais vantagens no uso da língua francesa nas escolas cristãs são descritas de maneira resumida por Justo (2003, p. 234). O aprendizado do francês é mais fácil e a leitura do francês possui maior utilidade na vida prática, e, como consequência, o aprendizado é mais rápido. As crianças permaneciam pouco tempo na vida escolar, e, com isso, aprender a leitura e escrita do francês era importante para, ao sair da escola, pelo menos, estariam alfabetizados e o aprendizado teria se tornado útil.

Nas escolas lassalistas, a leitura era um meio de formação, ressaltando que a partir de Século XVII a Igreja, através da ampla utilização da imprensa, tinha publicado diversos livros de moral e catecismo. Através dos livros em francês, os alunos aprendiam as técnicas de leitura, e os de nível mais avançado aprendiam o latim no livro dos saltérios. O Guia das Escolas Cristãs prescreve para os alunos que liam corretamente em francês e latim a leitura e o estudo do livro Regras do Decoro e da Urbanidade Cristãos, obra de La Salle, impressa pela primeira vez em 1703.

La Salle escreveu em 1699 um documento intitulado Memória em Favor da Leitura em Francês, documento publicado na língua portuguesa em 2012 pela Unilasalle Editora. O documento teve a intenção de rebater as críticas que La Salle recebeu sobre o fato de primeiro ensinar aos meninos a leitura em francês, e não em latim.

Com efeito, quando se começa a ensinar as crianças a leitura pelo francês, elas ao menos sabem ler bem ao saírem da escola; e, sabendo ler corretamente o francês, podem elas mesmas instruir-se na doutrina cristã, aprendê-la nos catecismos impressos, santificar os domingos e festas com a leitura de bons livros e com orações bem feitas em língua francesa (LA SALLE, 2012c, p. 32)

Para La Salle, o ensino deveria ser prático e ativo, de tal maneira que o aluno estivesse constantemente envolvido em atividades. O aluno aprendia a preparar os instrumentos de estudo: aprendia a talhar as penas de ganso para escrever; copiava e elaborava documentos que usaria em sua vida como recibos, contratos e procurações. Dessa maneira, fica claro que as escolas lassalistas preparavam os alunos para a vida real e para o exercício de algum ofício. Embora não se tivesse a plasticidade da ascensão social, a escola já preparava para as atividades que cada um exerceria. Muitas propostas educacionais apresentadas como inovações pedagógicas, séculos depois, já estavam presentes. Nossa hipótese é a de que quem não estuda, não conhece ou se esquece e, portanto, apresenta o antigo como novidade. Falaremos disso no final deste ensaio.

\section{O Instituto dos Irmãos das Escolas Cristãs no Brasil}

Os Irmãos Lassalistas chegaram ao Brasil no ano de 1907. Era um grupo formado por doze Irmãos vindos da França, Bélgica, Alemanha e Portugal. Tiveram a missão de estabelecer no Brasil o Instituto dos Irmãos das Escolas Cristãs. A primeira comunidade foi aberta em Porto Alegre e a segunda em Vacaria, Rio Grande do Sul. Desde 1842 havia pedidos para a vinda dos Irmãos Lassalistas ao Brasil. Os pedidos foram enviados de vários estados: Pará, Rio de Janeiro, Minas Gerais, São Paulo, Bahia, Mato Grosso e Rio Grande do Sul. Até o Instituto se consolidar no Brasil vieram aproximadamente cem Irmãos da França, Bélgica, Alemanha, Espanha, Portugal, Áustria e Itália. Após uma década no Brasil foram formados os primeiros Irmãos brasileiros e puderam atender as várias solicitações para abrir escolas nos outros estados (COMPAGNONI, 1980). 
Alguns Irmãos Lassalistas migraram da França para o Brasil devido aos conflitos entre o governo francês e a Igreja. As Congregações Religiosas não reconhecidas oficialmente foram expulsas da França em $1880^{15}$, pelo governo anticlerical. Em 1880 o Irmãos não foram expulsos da França porque tinham o reconhecimento oficial outorgado por Napoleão Bonaparte em 1808, que autorizava o funcionamento das escolas confessionais, supressas pela Revolução Francesa em 1789. Em 1900, na França, eram 10.600 Irmãos, com 1.500 escolas. Os Irmãos tinham visibilidade em toda a França. Porém, em 1907 todas as escolas foram confiscadas pelo governo dentro do princípio de laicização. Aproximadamente 3.500 Irmãos se secularizaram, ou seja, permaneceram com os votos, mas viveram fora das comunidades e mantinham o vínculo com as escolas. Dos outros 7.000, muitos deixaram o Instituto e os que continuaram Irmãos tiveram que sair da França. Até o ano de 1905, foram fechadas em torno de 7.000 escolas católicas masculinas e femininas. Esses decretos anticlericais afetaram substancialmente o Instituto dos Irmãos das Escolas Cristãs, pois, a partir daquela data, qualquer tipo de ensino realizado pelas Congregações Religiosas Católicas foi interditado e as Congregações autorizadas que tivessem o trabalho docente com exclusividade seriam suprimidas num prazo máximo de dez anos. (NERY, 2007). Por causa desses conflitos na França, houve a motivação da vinda dos Irmãos ao Brasil para dar continuidade às escolas cristãs. A primeira escola lassalista em território brasileiro iniciou suas atividades em 3 de junho de 1907, em Vacaria, Rio Grande do Sul, distante $300 \mathrm{~km}$ de Porto Alegre. A intenção era manter em Vacaria uma escola gratuita, seguindo a tradição do Instituto, mas nos primeiros meses de funcionamento os Irmãos encontraram várias dificuldades e o colégio encerrou suas atividades em dezembro de 1908 (COMPAGNONI, 1980).

Com mais de um século de atividades e obras educativas no Brasil, os Irmãos lassalistas mantêm escolas, centros de assistência social e centros universitários em dez estados e no Distrito Federal. A partir de 2012 houve unificação na administração das obras lassalistas no Brasil, Chile e Moçambique, constituindo uma única unidade administrativa e canônica, com sua sede em São Paulo. Ao todo são aproximadamente quarenta escolas de educação básica, uma dezena de obras assistenciais e seis centros universitários. Mais informações são encontradas no Portal La Salle http://www.lasalle.edu.br .

Atualmente o Instituto dos Irmãos das Escolas Lassalistas mantém aproximadamente mil e cem obras educativas em oitenta e dois países, sendo mais de sessenta universidades e centros universitários, cerca de novecentos e cinquenta mil alunos, noventa mil educadores e cinco mil Irmãos. O portal do Instituto http://www.lasalle.org disponibiliza informações nas quatro línguas oficiais do Instituto e links para conectar os sites das instituições em cada país.

O Instituto disponibiliza o acervo digital das obras completas de La Salle em língua francesa e de obras selecionadas de La Salle, traduzidas para a língua espanhola. http://www.delasalle.qc.ca/fr/ecrits_du_fondateur.asp?pageID=345 http://www.lasalle.org/recursos/publicaciones/escritos-del-fundador/

O Instituto mantém a A Revista Digital de Investigação Lassaliana com uma publicação semestral online, cujo objetivo é a difusão de artigos de investigação, ensaios, documentos, resenhas de livros e eventos para os Lassalianos. http://revista_roma.delasalle.edu.mx/index.php?lan=es 


\section{Considerações finais: silêncio eloquente ou desconhecimento injustificado?}

No início do ano de 2013, no Programa de Pós-Graduação em Educação da UFSCar, na disciplina Estudos avançados em filosofia da educação, levantamos a seguinte questão: qual a contribuição dos católicos na constituição da escola na modernidade ocidental e quais traços continuam vivos na contemporaneidade? Mario Manacorda, numa obra de 382 páginas $^{16}$, dedica oito páginas à obra educacional de La Salle. É uma proporção considerável (passa de $2 \%$ do total da obra). E, além disso, suas considerações são bastante significativas, pois, ao analisar o Guia das Escolas Cristãs, ele nos diz que o regulamento escolar nos permite, por assim dizer, entrar na própria escola (MANACORDA, 1992, p. 228). E o pensador italiano conclui dizendo que

Poderíamos ter citado tantos outros estatutos de escolas e de colégios, especialmente do século XVI, e tantos projetos, embora parcialmente realizados [...]. Mas este é, talvez o mais pormenorizado (MANACORDA, 1992, p.235).

Foi exatamente essa a sensação que os estudantes da pós-graduação tiveram ao estudarem esse Guia $^{17}$. Descobriram que ali estavam os princípios da organização da escola moderna, e por que não dizer, contemporânea, em todos os seus detalhes. Tudo estava definido nas 290 páginas da edição em língua portuguesa. Algumas vezes, nessa disciplina da Pós-Graduação, repetiu-se com Cazuza: Eu vejo o futuro repetir o passado, eu vejo um museu de grandes novidades. O tempo não para...

No entanto, ao abrirmos a imensa maioria dos manuais de história e filosofia da educação, ao consultarmos as listas de teses e dissertações, algumas matrizes mereceram e continuam tendo bastante atenção, como é o caso dos jesuítas, enquanto outras fontes fundamentais, como o Guia das Escolas Cristãs de João Batista de La Salle, são praticamente esquecidas.

Consultamos os manuais escritos no Brasil e bastante utilizados nos cursos de pedagogia e de licenciaturas e pensamos em comentá-los. Desistimos, pois não havia o que comentar. Construiu-se um silêncio eloquente em torno da obra educacional de La Salle. Os estudantes concluem história da educação, filosofia da educação ou sociologia da educação, como se ele não tivesse existido, mesmo que os tempos e espaços da escola moderna e contemporânea tivessem nele e nos Irmãos das Escolas Cristãs os seus maestros.

Depois de tudo estudar, soou estranho que um manual como o de Franco Cambi, que pretende ser uma História da Pedagogia, em 700 páginas, dedique apenas meia página a La Salle, e de forma tão desairosa, e que em nada contribui para informar o leitor. Diz Cambi (1999, p.299):

O aspecto central do seu projeto educativo é, todavia, a instrução religiosa, desenvolvida na direção mística e ascética, por meio do ensino catequético e de expedientes de vários tipos. No início de cada lição (e também a cada hora ou meia hora) lembra-se ao aluno a "presença de Deus", a fim de reforçar o conceito na sua mente e consciência, ou então são recitadas orações ininterruptamente segundo turnos estabelecidos. Por essas práticas religiosas e do culto ao silêncio tende-se a criar no aluno uma atmosfera de seriedade e de rigor, alheia ao riso e ao jogo, e regulada por severas punições. 
Para quem tem apenas meia página para falar sobre La Salle, certamente esse não é o ponto central nem o resumo de sua obra. O leitor que se sentir provocado à leitura da obra do fundador das Escolas Cristãs poderá ser o juiz dessas afirmações. Por enquanto, pelo menos Manacorda não concorda com Cambi. Nem com aqueles que silenciam sobre La Salle.

Quem leu apenas Marx, fala sobre Marx. Quem leu apenas Freud, ensina Freud. Mas Marx e Freud tiveram formação universal e discutiram todos os autores. E Manacorda, que é marxista, dedica oito páginas de sua História da Educação a La Salle. Portanto, parece haver algo errado, segundo nossa hipótese, na prática do ensino dessa área de conhecimento nos cursos de pedagogia e de pós-graduação em educação, tanto quanto nas obras de divulgação que formam os estudantes. Seria um silêncio eloquente ou uma demonstração de mero desconhecimento, injustificado, obviamente. Ninguém fala sobre o que não conhece. E todos continuam descrevendo apenas o próprio quintal. A formação deixa de ser omnilateral. Os estudantes que cursaram a disciplina citada acima concluíram que, sem conhecimento, não têm condição nem de fazer a crítica. É preciso saber distinguir: uma coisa é ter uma formação marxista; outra coisa é um estudo sobre Marx.

No estudo dos textos que fundamentam a educação católica e, em grande parte, modelam a escola moderna, cujas marcas estão indelevelmente presentes na escola contemporânea, nós os encontramos de tempos em tempos, fortemente determinantes:

$$
\begin{aligned}
& \text { +- } 1250 \text { - De Magistro (Tomás de Aquino) } \\
& 1599 \text { - Ratio Studiorum (Jesuístas) } \\
& 1706 \text { - Guia das Escolas Cristãs de La Salle } \\
& 1856 \text { - Guia das Escolas de Marcelino Champagnat (Maristas) }
\end{aligned}
$$

Com exceção do intervalo maior entre Tomás de Aquino e o Ratio, os outros documentos aparecem a cada cento e cinquenta anos. São documentos e movimentos de educação que se espalham pela Europa e depois por outros países, em especial pela América Latina. Este ensaio pode despertar projetos de mestrado e doutorado em educação para o preenchimento de uma grande lacuna. E talvez, no futuro, o Guia não mereça apenas meia página de forma tão desairosa numa obra de 700 páginas!

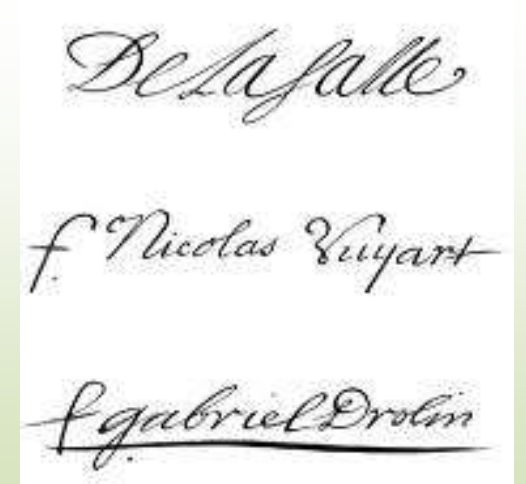

Esta montagem reúne as assinaturas autênticas dos três que proferem o "voto heroico" (21 de novembro de 1691). O Senhor De La Salle, Gabriel Drolin e Nicolás Vuyart se comprometem por voto de associação e união a trabalhar no estabelecimento da "Sociedade das Escolas Cristãs", ainda que "apenas nós três permaneçamos na dita Sociedade e sejamos obrigados a mendigar e a viver somente de pão".

http://www.lasalle2.org/spanish/Resources/ClipArt/iconog.php 


\section{Referências}

CAMBI, Franco. História da pedagogia. Trad. Álvaro Locencini. São Paulo: Fundação Editora da UNESP, 1999.

COMPAGNONI, Ivo Carlos. História dos Irmãos Lassalistas no Brasil. Canoas: Editora La Salle, 1980.

HENGEMÜLE, Edgard. La Salle, uma leitura de leituras: o padroeiro dos professores na história da educação. Canoas, RS: Centro Universitário La Salle, [199-].

JUSTO, Henrique. La Salle: patrono do magistério, vida, escritos, inovações pedagógicas.

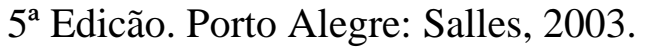

LA SALLE, João Batista de. Cartas. Coleção: Obras completas de São João Batista de La Salle. Volume I - A. Canoas: Unilasalle, 2012a.

LA SALlE, João Batista de. Regras Comuns dos Irmãos das Escolas Cristãs. Coleção: Obras completas de São João Batista de La Salle. Volume II A. Canoas: Unilasalle, 2012d.

LA SALLE, João Batista de. Regras do Decoro e da Urbanidade Cristãos. Coleção: Obras completas de São João Batista de La Salle. Volume III. Canoas: Unilasalle, 2012e.

LA SALLE, João Batista de. Guia das Escolas Cristãs. Canoas: Editora Unilasalle, 2012b.

LA SALLE, João Batista de. Honrar o Ministério: A dimensão educativa nas meditações de La Salle. Canoas: Ed. Unilasalle, 2013.

LA SALLE, João Batista de. Memória em favor da Leitura em Francês. Canoas: Editora Unilasalle, 2012c.

LAURAIRE, Léon. La Guía de las escuelas enfoque pedagógico. Cahier lasalliens. Maison Saint Jean-Baptiste de La Salle: Roma, 2006.

MANACORDA, Mario Alighiero. História da educação: da antiguidade aos nossos dias. Trad. Gaetano Lo Monaco. $3^{\text {a }}$ edição. São Paulo: Cortez, Autores Associados, 1992.

NERY, Irmão. A saga dos pioneiros lassalistas no Brasil. Niterói, RJ: La Salle, 2007.

PIANTKOSKI, Marcelo Adriano. Princípios educativos lassalistas: o currículo prescrito do colégio Diocesano LaSalle de São Carlos/SP. 131 f. Dissertação de Mestrado. Centro Universitário Moura Lacerda: Ribeirão Preto, 2010.

POUTET, Yves; PUNGIER, Jean. La Salle e os desafios de seu tempo. (tradução Henrique Justo) Canoas: La Salle, 2001.

SALM, Luke. Señor, Es Tu Obra: Vida de San Juan Bautista de La Salle. Región Latinoamericana Lassalista, 2004.

Notas

\footnotetext{
${ }^{1}$ Doutor em Educação, Departamento de Educação, Programa de Pós-Graduação em Educação, Universidade Federal de São Carlos - UFSCar

${ }^{2}$ Mestrado em Educação pelo Centro Universitário Moura Lacerda de Ribeirão Preto, Licenciatura em Filosofia pela Universidade Católica de Brasília, Diretor do Colégio La Salle São Carlos - SP, Membro do Conselho de Educação e Pastoral da Rede La Salle Brasil-Chile.
} 
${ }^{3}$ Mais informações sobre a iconografia utilizada neste ensaio podem ser encontradas em: http://www.lasalle2.org/spanish/Resources/ClipArt/iconog.php, acessada em 28 de novembro de 2013, ou no novo site da ordem citado no final do ensaio.

${ }^{4}$ Este é o ano do início do reinado absoluto de Luiz XIV, com a morte do Cardeal Mazarino, que era o coregente, durante sua menoridade.

${ }^{5}$ No século XVI, na França, Montaigne evocava a velhice aos 30 anos de idade! No XVII, aos 40 anos.

${ }^{6}$ Romance de Victor Hugo (1802 - 1885) ambientado na França do século XIX.

${ }^{7}$ Essa teoria é defendida na obra póstuma "Os fundamentos da política na Sagrada Escritura" (1709). Pode-se ler o original do argumento de Bossuet em: http://www.abbaye-saint-benoit.ch/bossuet/volume023/014.htm, parte da obra La Politique tirée de l'Écriture sainte.

${ }^{8}$ Orações e cânticos dos salmos para as várias horas do dia.

${ }^{9}$ Compromissos para sempre, diferentes dos votos temporários.

${ }^{10}$ Quem estuda a vida e a obra dos educadores certamente considerará estranha essa decisão de La Salle. Deve-se levar em consideração que se tratava de um educador, antes de tudo, com alma religiosa que se preocupava em educar as crianças para este e para o outro mundo, cuidar do corpo e da alma, mas que também precisava salvar a própria alma. Sentindo-se próximo ao fim da "jornada" procurou uma vida de retiro, de ermitão para meditar sobre sua vida, para desapegar-se de tudo, para estar livre para partir deste mundo. Essa era a sua lógica. Bem diferente daqueles que constroem um império educacional e jamais querem se desgarrar dele. Ou que se acham imprescindíveis.

${ }^{11}$ Sim, há um De magistro, também de Tomás de Aquino (conhece-se, em geral, o De magistro, de Agostinho)

${ }^{12}$ Sobre a formação dos padres no seminário menor tridentino (segundo as determinações do Concílio de Trento), no modelo de internato, está disponível para download gratuito a dissertação de mestrado de João Virgílio Tagliavini, intitulada Garotos no túnel: a imposição da vocação sacerdotal e o processo de condicionamento nos seminários menores tridentinos, na biblioteca digital da UNICAMP, no seguinte endereço eletrônico: http://www.bibliotecadigital.unicamp.br/document/?code=000028869\&opt=4. É uma obra de referência.

${ }^{13}$ Encontram-se as Obras completas de João Batista de La Salle no original, para download gratuito, no endereço eletrônico: http://www.delasalle.qc.ca/fr/ecrits_du_fondateur.asp?pageID=345.

${ }^{14}$ É possível ler o Guia das Escolas Cristãs em espanhol na internet: http://www.lasalle.org/wpcontent/uploads/pdf/estudios_lasalianos/ocjbs_es/09-guia_escuelas.pdf, ou no original em francês: http://www.delasalle.qc.ca/documents/107/conduite des_ecoles.pdf

${ }^{15}$ O então ministro da Instrução Pública da França (1879-1881), Jules Ferry, republicano, ateu e francomaçon, faz a reforma de uma educação laica e gratuita que colocará empecilhos para as escolas confessionais.

${ }^{16}$ Referência à História da educação, citada na bibiografia.

${ }^{17}$ Cada inscrito na disciplina recebeu do Irmão Marcelo um Guia, de presente, o que facilitou o estudo. Irmão Marcelo Piantkoski colaborou na disciplina, apresentando a vida e a obra de João Batista de La Salle, e dessa participação surgiu a necessidade de escrever um ensaio para uma revista ou um pequeno livro para os estudantes brasileiros, para o preenchimento dessa lacuna. A oportunidade veio em seguida para ser publicado na revista do Histedbr.

Recebido em outubro-13

Aprovado em novembro-13 